\title{
EFFECTS OF NANO FERTILIZER APPLICATION AND MATERNAL CORM WEIGHT ON FLOWERING OF SOME SAFFRON (Crocus sativus L.) ECOTYPES
}

\author{
Reza AMIRNIA ${ }^{l}$, Mahdi BAYAT ${ }^{l^{*}}$, Mahdi TAJBAKHSH ${ }^{l}$ \\ Urmia University, Faculty of Agriculture, Department of Agronomy, Urmia, IRAN \\ * Corresponding author: mahdibayat971@gmail.com
}

Received: 06.03.2014

\begin{abstract}
To develop saffron planting in Urmia, West Azerbaijan, Iran, a split-split plot experiment based on CRBD was carried out in the Urmia University's research farm for two years (2013-14). Nanofertilizers (Fe, P, K and nofertilizer (control)) as main plots, saffron ecotypes (Mashhad, Torbat-Heydarieh, Torbat-jam, Gonabad, Ghaen and Birjand) as subplots and maternal corm weight $(6,8,10$ and $12 \mathrm{~g})$ as sub-sub plots were considered. Throughout the two years of the study, results showed significant differences between nanofertilizers levels, saffron ecotypes, maternal corm weight and their interactions in terms of all flowering traits. Results highlighted the importance of the nanofertilizers on improving saffron yield. In addition, it was also clear that $\mathrm{Fe}, \mathrm{P}$ and $\mathrm{K}$ nanofertilizers all had positive effects on the saffron flowering. The results also illustrated that the high yield ecotypes Torbat-Heydarieh and Mashhad in Urmia region were due to similar climatic conditions of these regions. These results emphasized the importance of the mother corm weight on increasing saffron flowering was much better than both the nanofertilizer and saffron ecotype. As the mother corm weight increases from 6 to 12 grams, all the studied traits, including dry saffron yield and flower number also increased, by 5.17 times and 4.4 times, respectively. The results of stepwise regression and correlation coefficients noted that flower number, dry and fresh flower weight were the most effective traits on dry saffron yield. In total, it was concluded that saffron flowering traits are strongly influenced by environmental conditions and farm management. Therefore, the correct choice of saffron ecotypes, nanofertilizer and maternal corm weight are vital factors in farm management and economic saffron production.
\end{abstract}

Keywords: Correlation Coefficients, Saffron Ecotypes, Stepwise Regression, saffron yield.

*The part of PhD thesis results of the corresponding author, MAHDI BAYAT

\section{INTRODUCTION}

Saffron is a spice derived from the dried stigma of the Crocus sativus flower, which is a sterile triploid plant that propagated by means of corms (Botella, et al., 2002; Gómez-Gómez, 2012). From the ancient times, the red scarlet stigmas of saffron have been used mainly in drug applications, textile dye, incense, cosmetics and food purposes (Zdemür, et al., 2006; Juana, et al., 2009; RubioMoraga, et al., 2009, Anastasaki, et al., 2010). Recently, there has been increasing interest in the biological effects of the components of saffron. In particular, their potential medical applications, especially those based on their cytotoxic, mood elevating, liver detoxifying, analgesic and antitumor properties (Ma, et al., 2001; Abdullaev, 2003; Schmidt, et al., 2007; Siracusa, et al., 2010). For these reasons, saffron is the world's most expensive spice (Kafi, 2006). Saffron is currently being cultivated in Morocco, Spain, Iran, India, Pakistan, Turkey, Italy, Switzerland, Greece and Central Asia. Additionally, new cultivations have been created in Australia, Mexico, Argentine and New Zealand. Among the saffron producing countries, Iran is one of the main producers of saffron in the world (Jalali-Heravi, et al., 2010).

Much information is available on the use of saffron as a dye, aroma and for medicinal purposes, but there is a lack of information on its climatic requirements, agronomic management techniques and their effects on its quantitative and qualitative traits. From an agronomic point of view, saffron is actually very well adapted to different environmental conditions ranging from dry subtropical to continental climates (Azizbekova and Milyaeva, 1999; Sampathu, et al., 1984; Gresta, et al., 2009). Mollafilabi (2004) and Fernandez (2004) suggested that the optimal climatic conditions for this species are rainy autumns, mild winters and warm summers. The effect of the corm weight at planting the saffron quantitative yield has been studied by Salinger (1991); Rees (1992); Negbi (1999); De Juan, et al., (2003); 
Molina, et al., (2004) and Renau-Morata, et al., (2012). These researchers reported that the weight of the mother corm has a significant effect on the vegetative development and the production of daughter corms. The effect of the different saffron corms proveniences on stigmas yield and qualitative traits of saffron has been studied by several researchers such as Molina, et al., (2005); Castillo, et al., (2005); Rubio-Moraga, et al., (2009); Siracusa et al., (2010); Anastasaki, et al., (2010) and Maggi, et al., 2011). These authors pointed out that the environment and climatic conditions, for example: temperature, soil and water content, have severe effect on both quantitative and qualitative traits of saffron.

Because of the limitation in arable lands and water resources, the development of agriculture sector is only possible by increasing of resources use efficiency with the minimum damage to production bed through effective use of modern technologies. Among these, nanotechnology has the potential to revolutionize the agricultural systems (Baruah and Dutta, 2009). Recent research on nanoparticles in a number of crops has evidenced for enhanced germination and seedling growth, physiological activities, gene expression and protein level indicating their potential use in crop improvement (Kole, et al., 2013). In this way, Azarpour, et al., (2013) reported nano iron fertilizers foliar spraying had significant effects at $1 \%$ probability level on fresh flower cover yield of saffron. In addition, Studies showed that the use of nanofertilizers causes an increase in nutrients use efficiency, reduces soil toxicity, minimizes the potential negative effects associated with over dosage and reduces the frequency of the application. Hence, nanotechnology has a high potential for achieving sustainable agriculture, especially in developing countries (Naderi and Danesh-Shahraki, 2013).

Besides the expanding employment opportunities, Saffron can contribute to the economy of Iran by earning and saving valuable foreign exchange. Therefore, the aim of this study is to investigate the agricultural practices with the hope of improving saffron yield and flowering traits, in order to determine the optimum levels of maternal corm weight, nanofertilizer and saffron ecotypes. It is our hope that this work will eventually establish a new standard of agricultural practices which will optimize Saffron yields in the Urmia region.

\section{MATERIALS AND METHODS}

To develop saffron (Crocus sativus L.) planting in Urmia, West Azerbaijan, Iran, a split-split plot experiment based on CRBD was carried out in the research farm of Urmia University for the years of 2013-2014. Nano fertilizers ( $\mathrm{Fe}, \mathrm{P}, \mathrm{K}$ and no-fertilizer (control)) as main plots, saffron ecotypes (Mashhad, Torbat-Heydarieh, Torbat-jam, Gonabad, Ghaen and Birjand) (Table 1) as subplots and maternal corm weight $(6,8,10$ and $12 \mathrm{~g})$ as sub-sub plots were considered. Six saffron samples from different regions of Iran's traditional saffron production areas were studied in this work. The geographic and climatic characteristics of each region are shown in Tables 1 and 2 .

Table 1. Geographic characteristics of regions.

\begin{tabular}{|c|c|c|c|c|c|c|}
\hline No & Region & Province & Country & Elevation (M) & Longitude (E) & Latitude (N) \\
\hline 1 & Mashhad & Razavi Khorasan & Iran & 999.2 & $38^{\circ} 59^{\prime}$ & $16^{\circ} 36^{\prime}$ \\
\hline 2 & Torbat Jam & Razavi Khorasan & Iran & 1056 & $58^{\circ} 41^{\prime}$ & $34^{\circ} 21^{\prime}$ \\
\hline 3 & Gonabad & Razavi Khorasan & Iran & 1450.8 & $13^{\circ} 59^{\prime}$ & $16^{\circ} 35^{\prime}$ \\
\hline 4 & Torbat Heidarish & Razavi Khorasan & Iran & 950.4 & $35^{\circ} 60^{\prime}$ & $15^{\circ} 35^{\prime}$ \\
\hline 5 & Birjand & South Khorasan & Iran & 1491 & $59^{\circ} 12^{\prime}$ & $32^{\circ} 52^{\prime}$ \\
\hline 6 & Gaean & South Khorasan & Iran & 1432 & $59^{\circ} \quad 10^{\prime}$ & $33^{\circ} 43^{\prime}$ \\
\hline 7 & Urmia & West Azerbaijan & Iran & 1315.9 & $45^{\circ} \quad 05^{\prime}$ & $37^{\circ} \quad 32^{\prime}$ \\
\hline
\end{tabular}

Table 2. Climatic characteristics of regions based on the 30 years average.

\begin{tabular}{lllllll}
\hline Station & $\begin{array}{l}\text { Maximum } \\
\text { Temperature } \\
\left(\mathbf{C}^{\circ}\right)\end{array}$ & $\begin{array}{l}\text { Minimum } \\
\text { Temperature } \\
\left(\mathbf{C}^{\circ}\right)\end{array}$ & $\begin{array}{l}\text { Mean Daily } \\
\text { Temperature } \\
\left(\mathbf{C}^{\circ}\right)\end{array}$ & $\begin{array}{l}\text { Relative } \\
\text { Humidity } \\
(\boldsymbol{\%})\end{array}$ & $\begin{array}{l}\text { Monthly } \\
\text { Total Of } \\
\text { Precipitation } \\
(\mathbf{M m})\end{array}$ & $\begin{array}{l}\text { Days With } \\
\text { Minimum } \\
\text { Temperature } \\
\text { Equal Zero And } \\
\text { Below }\end{array}$ \\
\hline $\begin{array}{l}\text { Mashhad } \\
\text { Gonabad }\end{array}$ & 21.1 & 7.1 & 14.1 & 55 & 255.2 & 89.3 \\
Torbate & 23.8 & 10.7 & 17.3 & 37 & 143.6 & 49.2 \\
$\begin{array}{l}\text { Heydarieh } \\
\text { Torbate Jam }\end{array}$ & 21.3 & 7.3 & 14.3 & 46 & 274.8 & 95.7 \\
Birjand & 22.4 & 8.8 & 15.6 & 45 & 175.6 & 73.6 \\
Ghaen & 24.5 & 8.4 & 16.5 & 36 & 170.8 & 76.2 \\
\hline Mean & 22.3 & 6.3 & 14.3 & 37 & 175.8 & 93.8 \\
\hline Urmia & 22.6 & 8.1 & 15.4 & 42.7 & 199.3 & 22.6 \\
\hline
\end{tabular}


In terms of the soil characteristics at the research farm, the soil texture is a silty-loam structure containing $1.5 \%$ of organic carbon and $0.03 \%$ of nitrogen, in addition to 25 p.p.m of phosphorus and 534 p.p.m of potassium. The soil acidity was indicated at a $\mathrm{pH}$ of 7.7 at a depth of $0-30 \mathrm{~cm}$. After preparing the field on April 15, 2013; the cultivation practices applied were those commonly used for this crop. Every plot contained 8 culture lines, each of which were 3 meters in length and placed $25 \mathrm{~cm}$ apart from each other. The total plot area was $6 \mathrm{~m}^{2}$. Corm distances on the lines were $8 \mathrm{~cm}$ and placed at a depth of $15 \mathrm{~cm}$. The density of the corm placement was 50 corms per $\mathrm{m}^{2}$. To avoid marginal effects and to minimize error, plots were situated beside each other no closer than $50 \mathrm{~cm}$. To enhance accuracy, margins were placed at the beginning and the end of plots as well as the $50 \mathrm{~cm}$ border between each plot. Nano fertilizers were sprayed twice in the months of January and February. Data were recorded for Dry Saffron Yield $\left(\mathrm{kg} \mathrm{ha}^{-1}\right)(\mathrm{DSY})$, Flower Number $\left(\mathrm{m}^{2}\right)(\mathrm{FN})$, Fresh Stigma Weight (mg) (FSW), Dry Stigma Weight (mg) (DSW), Stigma Length (cm) (SL), Fresh Flower Weight (mg) (FWF) and Dry Flower Weight (mg) (DFW). The relationships between these traits using simple correlation coefficients were studied. Step-wise regression analysis was done to fit the best model for existent variation in dry saffron yield as the dependent variable. The cluster analysis based on Ward's method was also used to classify saffron ecotypes. Data analysis was done using SAS ver. 9.2 and SPSS ver. 21 programs.

\section{RESULTS AND DISCUSSION}

\section{Analysis of Variance}

The results of the variance analysis (Table 3) indicated significant differences between years, nano-fertilizers, saffron ecotypes, maternal corm weight and their interactions in terms of all flowering traits. This result implicated that flowering traits and dry saffron yield (DSY) were strongly influenced by environmental conditions and farm management. Therefore, the correct choice of saffron ecotypes, nanofertilizer and maternal corm weight can be considered the crucial factors in farm management and economic saffron production

Table 3. Variance analysis of flowering characteristics in saffron.

\begin{tabular}{|c|c|c|c|c|c|c|c|c|}
\hline \multirow[b]{2}{*}{ S.O.V } & \multirow[b]{2}{*}{ Df } & \multicolumn{7}{|c|}{ Mean Square } \\
\hline & & DSY $\left(\mathrm{kg} \mathrm{ha}^{-1}\right)$ & FN $\left(\mathrm{m}^{2}\right)$ & FSW (mg) & DSW (mg) & SL (cm) & FFW (mg) & DFW (mg) \\
\hline$Y^{*}$ & 1 & $252.02 * *$ & $69548.90 * *$ & $109.05^{\mathrm{ns}}$ & $29.88 *$ & $8.51^{\mathrm{ns}}$ & $1918.18^{\text {ns }}$ & $146.10^{\mathrm{ns}}$ \\
\hline Error $_{\mathrm{a}}$ & 2 & 0.12 & 14.41 & 143.69 & 2.86 & 3.29 & 3505.13 & 86.80 \\
\hline $\mathrm{F}$ & 3 & $3.98 * *$ & $278.18 * *$ & $123.51 * *$ & $7.80 * *$ & $8.90 * *$ & $5908.26 * *$ & $250.73 * *$ \\
\hline $\mathrm{F}^{*} \mathrm{Y}$ & 3 & $2.24 * *$ & $263.94 * *$ & $113.46 * *$ & $7.23 * *$ & $1.29 * *$ & $880.03 *$ & $50.02 *$ \\
\hline Error $_{b}$ & 6 & 0.03 & 8.86 & 8.07 & 0.43 & 0.19 & 197.83 & 11.84 \\
\hline $\mathrm{E}$ & 5 & $3.98 * *$ & $234.28 * *$ & $142.51 * *$ & $15.51 * *$ & $2.93 * *$ & $3320.89 * *$ & $47.53 * *$ \\
\hline $\mathrm{E}^{*} \mathrm{~F}$ & 15 & $0.18 * *$ & $14.92 * *$ & $23.89 * *$ & $1.07 * *$ & $0.44 *$ & $581.16 * *$ & $32.95 * *$ \\
\hline $\mathrm{E}^{*} \mathrm{Y}$ & 5 & $0.10 *$ & $16.15 *$ & $14.37^{\mathrm{ns}}$ & $0.33^{\mathrm{ns}}$ & $2.59 * *$ & $1139.30 * *$ & $99.78 * *$ \\
\hline $\mathrm{E}^{*} \mathrm{~F}^{*} \mathrm{Y}$ & 15 & $0.11 * *$ & $10.47 *$ & $18.59 * *$ & $0.72 *$ & $1.60 * *$ & $328.28 *$ & $27.32 * *$ \\
\hline Error $_{\mathrm{c}}$ & 40 & 0.04 & 5.83 & 7.71 & 0.34 & 0.22 & 162.33 & 6.30 \\
\hline $\mathrm{S}$ & 3 & $99.15 * *$ & $27628.20 * *$ & $429.47 * *$ & $13.26 * *$ & $11.36 * *$ & $90321.92 * *$ & $599.54 * *$ \\
\hline $\mathrm{S} * \mathrm{~F}$ & 9 & $0.44 * *$ & $56.34 * *$ & $1.18^{\mathrm{ns}}$ & $0.61 *$ & $0.33 *$ & $74.17^{\mathrm{ns}}$ & $2.40^{\mathrm{ns}}$ \\
\hline $\mathrm{S} * \mathrm{E}$ & 15 & $0.33 * *$ & $6.74 *$ & $11.25 *$ & $0.59 * *$ & $0.29 *$ & $609.94 * *$ & $16.06 * *$ \\
\hline $\mathrm{S}^{*} \mathrm{~F}^{*} \mathrm{E}$ & 45 & $0.09 * *$ & $8.23 * *$ & $2.60^{\mathrm{ns}}$ & $0.24^{\mathrm{ns}}$ & $0.12^{\mathrm{ns}}$ & $80.14^{\mathrm{ns}}$ & $4.40^{\mathrm{ns}}$ \\
\hline $\mathrm{S}^{*} \mathrm{Y}$ & 3 & $49.37 * *$ & $13738.30 * *$ & $12.63 *$ & $0.25^{\mathrm{ns}}$ & $2.63 * *$ & $219.29^{\mathrm{ns}}$ & $4.06^{\mathrm{ns}}$ \\
\hline $\mathrm{S}^{*} \mathrm{~F}^{*} \mathrm{Y}$ & 9 & $0.35 * *$ & $50.99 * *$ & $1.12^{\mathrm{ns}}$ & $0.27^{\mathrm{ns}}$ & $0.08^{\mathrm{ns}}$ & $36.48^{\mathrm{ns}}$ & $1.86^{\mathrm{ns}}$ \\
\hline $\mathrm{S}^{*} \mathrm{E}^{*} \mathrm{Y}$ & 15 & $0.21 * *$ & $6.34^{\mathrm{ns}}$ & $10.14 *$ & $0.56 * *$ & $0.44 * *$ & $614.61 * *$ & $15.26 * *$ \\
\hline $\mathrm{S}^{*} \mathrm{~F}^{*} \mathrm{E}^{*} \mathrm{Y}$ & 45 & $0.09 * *$ & $7.84 * *$ & $2.99^{\mathrm{ns}}$ & $0.29^{\mathrm{ns}}$ & $0.15^{\mathrm{ns}}$ & $72.07^{\mathrm{ns}}$ & $4.43^{\mathrm{ns}}$ \\
\hline Error $_{t}$ & 336 & 0.04 & 3.81 & 5.43 & 0.26 & 0.15 & 108.80 & 5.95 \\
\hline $\mathrm{CV}(\%)$ & --- & 14.0 & 7.8 & 8.4 & 9.8 & 10.9 & 13.1 & 5.7 \\
\hline
\end{tabular}

- Abbreviations described in materials and methods

$* *: p>0.01, *:$ p $>0.05$, ns: non-significant

\section{Mean Comparison of the Main Effects}

\section{Year}

The mean comparisons of the results across the two years are shown in Table 4 . The results showed that all saffron flowering traits especially dry saffron yield (DSY), flower number (FN) and dry stigma weight (DSW) increased in 2014 compared to 2013. However, the improvement of the flowering traits in the second year was predictable, because the saffron corms were carried from the easternmost province of Iran (Khorasan Razavi and Khorasan South) to the westernmost province of Iran (West Azarbaijan, Urmia). As shown in tables 1 and 2, climate characteristics of the easternmost province of Iran (average maximum temperature $22.6{ }^{\circ} \mathrm{C}$, average minimum temperature $8.1{ }^{\circ} \mathrm{C}$, average daily temperature $15.4{ }^{\circ} \mathrm{C}$, average relative humidity $42.7 \%$, average monthly total precipitation $199.3 \mathrm{~mm}$ and average number of days with minimum temperature equal zero and below 22.6 days) were different from climate characteristics of the westernmost province of Iran (average maximum temperature $17.6{ }^{\circ} \mathrm{C}$, average minimum temperature 5.4 
${ }^{\circ} \mathrm{C}$, average daily temperature $11.5{ }^{\circ} \mathrm{C}$, average relative humidity of $60.0 \%$, average monthly total precipitation $341.0 \mathrm{~mm}$ and average number of days with minimum temperature equal zero and below 110.6 days). As a result, the saffron corms were highly stressed in the first year; consequently, the flowering traits and saffron yield were extremely reduced. Nonetheless, in the second year, saffron corms not only adapted to Urmia environmental conditions but also produced more daughter corms, so that saffron flowering traits, especially DSY and FN increased dramatically.

Table 4. Mean compression of flowering traits in saffron.

\begin{tabular}{|c|c|c|c|c|c|c|c|}
\hline Treatment & $\begin{array}{l}\text { DSY } \\
\left(\mathrm{kg} \mathrm{ha}^{-1}\right)\end{array}$ & $\mathrm{FN}\left(\mathrm{m}^{2}\right)$ & $\begin{array}{l}\text { FSW } \\
\text { (mg) }\end{array}$ & DSW (mg) & SL $(\mathbf{c m})$ & $\begin{array}{l}\text { FFW } \\
\text { (mg) }\end{array}$ & $\begin{array}{l}\text { DFW } \\
\text { (mg) }\end{array}$ \\
\hline \multicolumn{8}{|l|}{ Year } \\
\hline 2013 & $0.71 b *$ & $13.91 \mathrm{~b}$ & $27.25 \mathrm{a}$ & $5.01 \mathrm{~b}$ & $3.44 \mathrm{a}$ & $338.52 \mathrm{a}$ & $42.02 \mathrm{a}$ \\
\hline 2014 & $2.03 \mathrm{a}$ & $35.89 \mathrm{a}$ & $28.12 \mathrm{a}$ & $5.47 \mathrm{a}$ & $3.69 \mathrm{a}$ & $342.17 \mathrm{a}$ & $43.03 \mathrm{a}$ \\
\hline \multicolumn{8}{|l|}{ Nano Fertilizer } \\
\hline Control & $1.16 \mathrm{c}$ & $23.04 \mathrm{c}$ & $27.44 \mathrm{~b}-\mathrm{c}$ & $5.07 \mathrm{~b}$ & $3.23 \mathrm{c}$ & $336.80 \mathrm{~b}$ & $41.19 \mathrm{~b}$ \\
\hline $\mathrm{Fe}$ & $1.52 \mathrm{a}$ & $26.13 \mathrm{a}$ & $28.87 \mathrm{a}$ & $5.52 \mathrm{a}$ & $3.81 \mathrm{a}$ & $349.93 \mathrm{a}$ & $44.35 \mathrm{a}$ \\
\hline $\mathrm{K}$ & $1.30 \mathrm{~b}$ & $24.66 \mathrm{~b}$ & $26.64 \mathrm{c}$ & $5.02 \mathrm{~b}$ & $3.52 \mathrm{~b}$ & $336.89 \mathrm{~b}$ & $42.22 \mathrm{~b}$ \\
\hline $\mathrm{P}$ & $1.48 \mathrm{a}$ & $25.77 \mathrm{a}$ & $27.80 \mathrm{a}$ & $5.33 \mathrm{a}$ & $3.69 \mathrm{a}$ & $337.76 \mathrm{~b}$ & $42.36 \mathrm{~b}$ \\
\hline Mean of Nano Fertilizer & 1.43 & 25.52 & 27.77 & 5.29 & 3.67 & 341.53 & 42.98 \\
\hline Mean - Control & 0.27 & 2.48 & 0.33 & 0.22 & 0.44 & 4.73 & 1.79 \\
\hline \multicolumn{8}{|l|}{ Saffron Ecotype } \\
\hline Birjand & $1.28 \mathrm{~d}$ & $25.15 b$ & $27.24 \mathrm{~b}-\mathrm{c}$ & $4.87 \mathrm{~d}$ & $3.44 \mathrm{~b}-\mathrm{c}$ & $336.53 \mathrm{~b}$ & $42.42 \mathrm{a}-\mathrm{b}$ \\
\hline Ghaen & $1.15 \mathrm{e}$ & $22.83 \mathrm{c}$ & $26.25 \mathrm{c}$ & $4.82 \mathrm{~d}$ & $3.37 \mathrm{c}$ & $336.29 \mathrm{~b}$ & $41.42 \mathrm{~b}$ \\
\hline Gonabad & $1.18 \mathrm{e}$ & $23.26 \mathrm{c}$ & $26.46 \mathrm{c}$ & $5.06 \mathrm{c}-\mathrm{d}$ & $3.73 \mathrm{a}$ & $333.04 \mathrm{~b}$ & $42.35 \mathrm{a}-\mathrm{b}$ \\
\hline Mashhad & $1.52 \mathrm{~b}$ & $26.25 \mathrm{a}$ & $28.37 \mathrm{a}-\mathrm{b}$ & $5.54 \mathrm{~b}$ & $3.43 \mathrm{~b}-\mathrm{c}$ & $347.76 \mathrm{a}$ & $42.39 \mathrm{a}-\mathrm{b}$ \\
\hline Torbat-Heidarieh & $1.67 \mathrm{a}$ & $26.70 \mathrm{a}$ & $29.27 \mathrm{a}$ & $5.85 \mathrm{a}$ & $3.79 \mathrm{a}$ & $345.57 \mathrm{a}$ & $43.26 \mathrm{a}$ \\
\hline Torbat-Jam & $1.42 \mathrm{c}$ & $25.20 \mathrm{~b}$ & $28.52 \mathrm{a}$ & $5.29 \mathrm{c}$ & $3.62 \mathrm{a}-\mathrm{b}$ & $342.86 \mathrm{a}$ & $43.34 \mathrm{a}$ \\
\hline Cluster I & 1.53 & 26.05 & 28.72 & 5.56 & 3.61 & 345.42 & 42.98 \\
\hline Cluster II & 1.20 & 23.75 & 26.65 & 4.92 & 3.51 & 335.29 & 42.05 \\
\hline \multicolumn{8}{|l|}{ Maternal Corm } \\
\hline \multicolumn{8}{|l|}{ Weight (gr) } \\
\hline 6 & $0.47 \mathrm{~d}$ & $9.64 \mathrm{~d}$ & $25.53 \mathrm{~d}$ & $4.84 \mathrm{~d}$ & $3.26 \mathrm{c}$ & $307.56 \mathrm{c}$ & $40.00 \mathrm{c}$ \\
\hline 8 & $1.04 \mathrm{c}$ & $19.71 \mathrm{c}$ & $27.25 \mathrm{c}$ & $5.19 \mathrm{c}$ & $3.39 \mathrm{~b}$ & $334.01 \mathrm{~b}$ & $41.76 \mathrm{~b}$ \\
\hline 10 & $1.53 \mathrm{~b}$ & $27.83 \mathrm{~b}$ & $28.35 \mathrm{~b}$ & $5.38 \mathrm{~b}$ & $3.83 \mathrm{a}$ & $358.84 \mathrm{a}$ & $43.97 \mathrm{a}$ \\
\hline 12 & $2.43 \mathrm{a}$ & $42.42 \mathrm{a}$ & $29.60 \mathrm{a}$ & $5.54 \mathrm{a}$ & $3.77 \mathrm{a}$ & $360.96 \mathrm{a}$ & $44.38 \mathrm{a}$ \\
\hline Ratio 12 on 6 & 5.17 & 4.40 & 1.16 & 1.14 & 1.16 & 1.17 & 1.11 \\
\hline
\end{tabular}

\section{Nano-fertilizer}

The results of the mean comparison (Table 4) showed that nanofertilizers had a positive effect on all saffron flowering traits. In comparison to the control (nofertilizer), the nanofertilizers significantly increased dry saffron yield (DSY), flower number (FN), fresh stigma weight (FSW), dry stigma weight (DSW), stigma length (SL), fresh flower weight (FFW) and dry flower weight (DFW) up to $270 \mathrm{~g} \mathrm{ha}^{-1}, 2.48,0.33 \mathrm{mg}, 0.22 \mathrm{mg}, 0.44 \mathrm{~cm}$, $4.73 \mathrm{mg}$ and $1.79 \mathrm{mg}$, respectively. Overall, these results emphasized the positive effects of all three nanofertilizers, $\mathrm{Fe}, \mathrm{P}$ and $\mathrm{K}$, in the improvement saffron flowering traits. Behzad et al., (1992) stated that organic matter and cow manure applications elevated the fertility of soils in saffron cultivation. Some of the earlier studies on saffron argued that chemical fertilization alone did not much improve flower yield, unless applied together with organic material such as cow manure and sawdust (McGimpsey, et al., 1997; Behnia, et al., 1999; Unal and Cavusoglu, 2005). Rico et al., (2011) stated that nanotechnology have positive effects on plants included enhanced germination percentage and rate; length of root and shoot, and their ratio; and vegetative biomass of seedlings in many crop plants. Also Liu et al., (2010) found that nanocomposites were safe for wheat seed germination, emergence and growth of seedlings.

\section{Saffron ecotype}

The results of mean comparison (Table 4) showed the ecotypes Torbat-Heydarieh $\left(\mathrm{DSY}=1.67 \mathrm{~kg} \mathrm{ha}^{-1}, \mathrm{FN}=\right.$ 26.7) and Mashhad (DSY $=1.52 \mathrm{~kg} \mathrm{ha}^{-1}, \mathrm{FN}=26.25$ ) were as the best saffron ecotypes in the weather conditions of Urmia. While ecotypes Ghaen (DSY $=1.15 \mathrm{~kg} \mathrm{ha}^{-1}, \mathrm{FN}$ $=22.83$ ) and Gonabad (DSY $\left.=1.18 \mathrm{~kg} \mathrm{ha}^{-1}, \mathrm{FN}=23.26\right)$ did not thrive in the conditions and were considered the most inappropriate ecotypes in Urmia region. In this study, saffron ecotypes were collected from regions with 
different climatic characteristics, so the observed differences between the ecotypes were related to the different climatic characteristics. With the evaluation of the meteorological data (Tables 1 and 2) and performing the cluster analysis in terms of all climatic characteristics, it was found that the studied regions can be classified in two clusters (Figure 1). Cluster I contained the regions of Torbat-Jam, Birjand, Ghaen and Gonabad and Cluster II contained regions Mashhad, Torbat-Heydarieh and Urmia. These results confirmed that the climatic characteristics of the Urmia region had the most similarity to the climate characteristics of Mashhad and Torbat-Heydarih regions and had the lowest similarity to the climate characteristics of Torbat-Jam, Birjand, Ghaen and Gonabad regions. In total, it can conclude that for establishing a new saffron farm, considering the climate characteristics of the region is very important and plays an effective role in the improvement of the saffron yield. Rubio-Moraga, et al., (2009) reported that all accessions (43 ecotypes from 11 countries) appear as identical clones, not only because of morphological characteristics, but also at the molecular level. The observed differences in saffron quality are mainly due to the methodology followed in the processing of stigmas, independent of the species origin (Ordoudi and Tsimidou, 2004). On the other hand, Molina et al., (2004; 2005) reported that the number of flowers formed per corm and the time of flower emergence depended on the environment conditions such as temperature and timelifted corm.

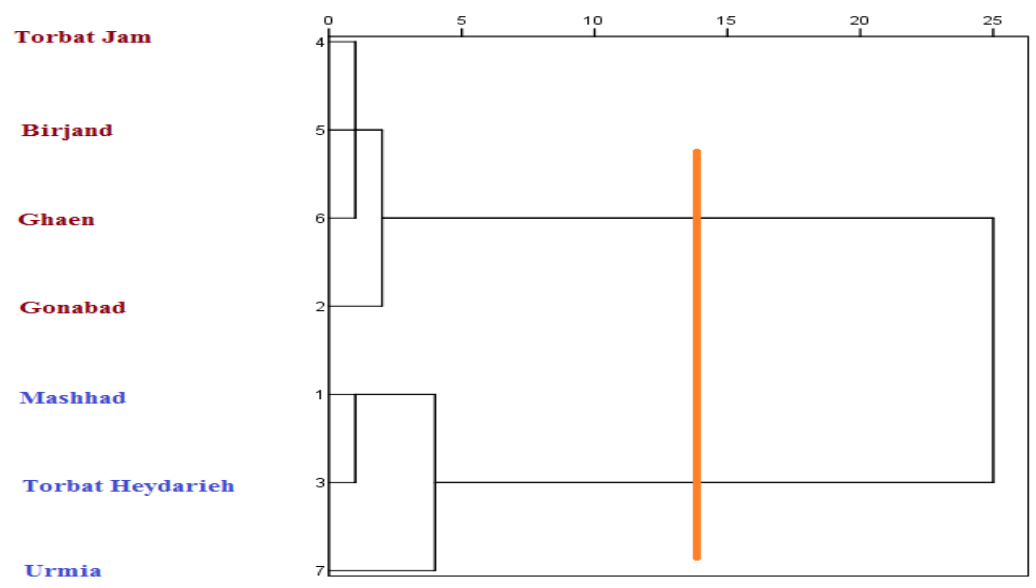

Figure 1. Dendrogram cities based on climatic characteristics using Ward's method.

Conversely, in order to classify the saffron ecotypes with respect to all studied flowering traits, the cluster analysis was used. The results showed six saffron ecotypes grouped in two clusters (Figure 2). Cluster I consisted ecotypes of Mashhad, Torbat-Heydarieh and Torbat-Jam and cluster II consisted ecotypes Birjand, Ghaen and Gonabad. When calculating the trait mean within each cluster (Table 4) it was revealed that all flowering traits of cluster I were superior to that of Cluster II. Therefore, it can be concluded that the ecotypes of cluster I were the most compatible with the Urmia climatic conditions, so these ecotypes can be introduced as the best saffron ecotypes in Urmia. It has previously been demonstrated that the geographical signals and regional agricultural practices, especially the use of fertilizers, in organic and conventional agriculture (Bateman and Kelly, 2007) effects the plant's production ability. Lage and Cantrell (2009) have grown saffron in eleven different experimental zones with differences in the altitudes, soils texture and climate. These results showed that environmental conditions have a great effect on saffron quality (Turhan, et al., 2007).

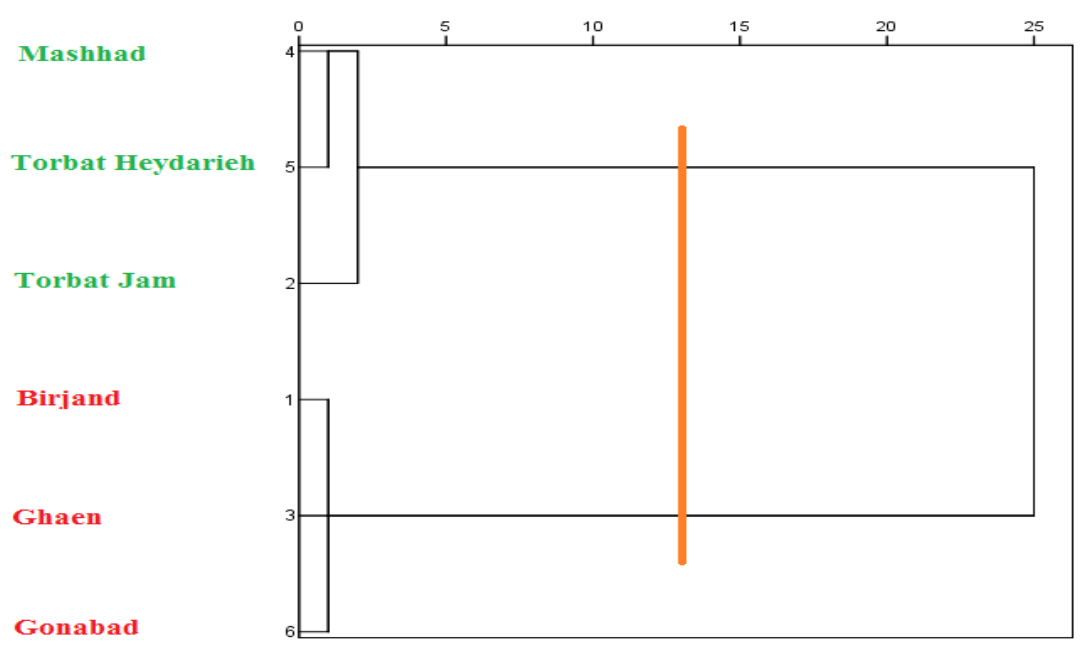

Figure 2. Dendrogram saffron ecotypes based on flowering characteristics using Ward's method. 


\section{Maternal corm weight}

The results of the mean comparison of maternal corm weight are shown in Table 4. The results emphasized the importance of maternal corm weight on improving saffron flowering and yield, which was much more significant than nanofertilizer and saffron ecotype effects. As mentioned above, increasing the maternal corm weight from 6 to 12 grams produced a corresponding significant increase all studied traits. DSY, FN, FSW, DSW, SL, FFW and DFW in corms of 12 grams, compared with corms of only 6 grams increased $5.17,4.4,1.16,1.14$, 1.16, 1.17 and 1.11 times, respectively (Table 4). These results showed that corms of 12 grams not only had more flower buds, but that also this corm size increased the saffron yield in the first year directly. Additionally, because of their ability to produce more daughter corms with higher weight, the saffron yield was able to increase dramatically in the coming years. In summary, it can be advised that saffron corms 10 grams and above are most suitable for establishing a new farm, while corms 6 grams and smaller are not recommended for use. Mollafilabi (2004) pointed out that planting corms above $3 \mathrm{~cm}$ diameter with an approximate weight of $10 \mathrm{~g}$ produced the highest yields. On the other hand, Negbi (1999); De Mastro and Ruta, (1993); Molina, et al., (2004) stated that there is an increase in the number of flowers per corm when larger corms are used at planting. Renau-Morata, et al., (2012) conclude that maternal corm weight determines if the corm will flower or not, given that if the corm does not reach a certain weight, it only produces leaves.

\section{Mean comparison of triple interaction effect (maternal corm weight $\times$ saffron ecotype $\times$ nano-fertilizer)}

The results of the mean comparison (Table 5) showed that the interaction effects $12 \mathrm{~g} \times$ Mashhad $\times \mathrm{Fe}, 12 \mathrm{~g} \times$ Torbat-Heydarieh $\times \mathrm{Fe}$ and $12 \mathrm{~g} \times$ Torbat-Jam $\times \mathrm{Fe}$ gained rank 1, 2 and 3, respectively, in terms of all studied flowering traits. Therefore, these interaction effects were identified as the most suitable effects in the Urmia climatic condition. On the other hand, interactions effects $6 \mathrm{~g} \times$ Birjand $\times$ control, $6 \mathrm{~g} \times$ Ghaen $\times$ control and $6 \mathrm{~g} \times$ Ghaen $\times \mathrm{K}$ received the highest $\operatorname{rank}(94,95$ and 96 respectively) were found as the weakest and had the most unsuitable interaction effects. In total, it was highlighted that maternal corm weight, nanofertilizer and saffron ecotype had the important roles when determining the potential of saffron yield, respectively. Therefore we recommended for establishing a new saffron farm, attention to the following notes: (i) The selection of better quality and larger saffron corms and performing the proper planting density. (ii) Fertilizers to be used in optimal times and doses. (iii) Saffron ecotypes to be supplied from regions where there is the maximum climate similarity between regions. With observing the above notes, saffron yield not only increases in the first year directly, but also increases in the coming years due to improved yield components. Some authors have proposed that an increase in the weight of the produced corms could improve saffron production (Juan, et al., 2009). On the other hand, corm formation of saffron is one of the important characteristics because the corm is the only source for propagation (Turhan, et al., 2007).

\section{Correlation Coefficients}

The results of correlation coefficients (Table 6) showed that there were positive and significant correlations between all studied flowering traits. Therefore any improvement in flowering traits will increase dry saffron yield. The results clearly demonstrate that dry saffron yield (DSY) had the highest correlation with flower number $(\mathrm{FN})\left(\mathrm{r}=0.98^{* *}\right)$. As explained earlier, larger saffron corms can produce more DSY in the first year due to have more flower bulbs. Moreover, larger saffron corms have higher quality, so that these corms can produce more daughter corms and subsequently will significantly increase DSY in the coming years (Mollafilabi, 2004; Renau-Morata et al., 2012). Within the course of this study, it also became clear that the nanofertilizers, especially $\mathrm{Fe}$ and $\mathrm{P}$ improved yield components especially FN and consequently increased DSY. In general, it can be concluded that increasing maternal corm weight and the use nanofertilizers will increase the yield components as well as the dry saffron yield, both directly and indirectly.

\section{Stepwise Regression}

In order to determine the most influential traits on dry saffron yield, stepwise regression was used. In this analysis, DSY as the dependent variable and the other traits as independent variables were considered. On the other hand, to achieve a more realistic understanding of traits effects on DSY, we used step by step regression for each year individually, and for the two years overall. The results of the stepwise regression in cropping year 2013 (Table 7) showed that the flower number (FN), dry stigma weight (DSW), stigma length (SL), fresh stigma weight (FSW) and fresh flower weight (FFW) entered into the regression model, was able to justify more than $91 \%$ of the variation of DSY. While, the results of stepwise regression in cropping year 2014 (Table 7) pointed out that FN, DSW, DFW and FFW justified more than $99 \%$ of the variation of DSY. The regression equation of DSY in 2013 and 2014 were as follows:

$$
\begin{aligned}
\mathrm{DSY}_{2013} & =0.494(\mathrm{FN})+0.424(\mathrm{DSW})+0.179(\mathrm{SL})- \\
0.186(\mathrm{FSW}) & +0.215(\mathrm{FFW}) \\
\mathrm{DSY}_{2014} & =0.934(\mathrm{FN})+0.214(\mathrm{DSW})-0.044(\mathrm{DFW})- \\
0.041(\mathrm{FFW}) &
\end{aligned}
$$

At last, the results of stepwise regression over the two cropping years (Table 7) highlighted that the traits FN, DSW and DFW were the most effective traits on DSY and justified more than $99 \%$ of the variation of DSY. The regression equation of DSY in total two cropping years was as follows:

$$
\mathrm{DSY}_{\text {total }}=0.911(\mathrm{FN})+0.181(\mathrm{DSW})-0.046(\mathrm{DFW})
$$


Table 5. Mean comparison of triple interaction effect (maternal corm weight $\times$ saffron ecotype $\times$ nanofertilizer) of flowering traits in saffron.

\begin{tabular}{|c|c|c|c|c|c|c|c|c|c|c|}
\hline Weight & Ecotype & Fertilizer & DSY & FN & FSW & DSW & SL & FFW & DFW & Rank \\
\hline 6 & Birjand & $\mathrm{Fe}$ & 0.44 & 9.93 & 25.01 & 4.46 & 3.48 & 308.65 & 40.62 & 87 \\
\hline 6 & Birjand & $\mathrm{P}$ & 0.44 & 10.06 & 25.67 & 4.28 & 3.16 & 301.00 & 37.23 & 91 \\
\hline 6 & Birjand & $\mathrm{K}$ & 0.46 & 9.85 & 25.42 & 4.59 & 3.17 & 298.70 & 41.75 & 88 \\
\hline 6 & Birjand & Control & 0.34 & 8.94 & 22.61 & 4.03 & 2.59 & 300.64 & 37.60 & 94 \\
\hline 6 & Torbat-Jam & $\mathrm{Fe}$ & 0.52 & 10.31 & 25.92 & 5.05 & 3.33 & 323.62 & 42.54 & 73 \\
\hline 6 & Torbat-Jam & $\mathrm{P}$ & 0.54 & 9.66 & 24.23 & 5.01 & 3.40 & 317.06 & 41.18 & 82 \\
\hline 6 & Torbat-Jam & $\mathrm{K}$ & 0.44 & 9.56 & 25.23 & 4.63 & 3.44 & 311.50 & 40.41 & 86 \\
\hline 6 & Torbat-Jam & Control & 0.50 & 10.59 & 25.52 & 4.86 & 2.79 & 311.37 & 40.54 & 90 \\
\hline 6 & Ghaen & $\mathrm{Fe}$ & 0.38 & 7.95 & 24.93 & 4.94 & 3.20 & 308.65 & 41.27 & 89 \\
\hline 6 & Ghaen & $\mathrm{P}$ & 0.35 & 8.24 & 24.71 & 4.44 & 3.35 & 301.00 & 38.18 & 92 \\
\hline 6 & Ghaen & $\mathrm{K}$ & 0.31 & 7.88 & 22.93 & 3.95 & 2.82 & 298.70 & 34.45 & 96 \\
\hline 6 & Ghaen & Control & 0.29 & 7.37 & 24.19 & 4.03 & 2.69 & 300.64 & 35.32 & 95 \\
\hline 6 & Mashhad & $\mathrm{Fe}$ & 0.66 & 11.17 & 29.14 & 5.80 & 3.40 & 323.62 & 42.57 & 55 \\
\hline 6 & Mashhad & $\mathrm{P}$ & 0.54 & 10.80 & 25.42 & 4.89 & 3.05 & 309.68 & 43.00 & 78 \\
\hline 6 & Mashhad & $\mathrm{K}$ & 0.57 & 10.68 & 25.07 & 5.04 & 3.03 & 313.09 & 41.67 & 83 \\
\hline 6 & Mashhad & Control & 0.55 & 10.75 & 26.98 & 4.97 & 3.14 & 317.15 & 38.51 & 77 \\
\hline 6 & Torbat-Heidarieh & $\mathrm{Fe}$ & 0.73 & 12.03 & 28.15 & 5.47 & 3.69 & 327.98 & 42.54 & 52 \\
\hline 6 & Torbat-Heidarieh & $\mathrm{P}$ & 0.66 & 11.37 & 27.22 & 5.49 & 3.48 & 314.79 & 41.80 & 65 \\
\hline 6 & Torbat-Heidarieh & $\mathrm{K}$ & 0.55 & 10.76 & 24.97 & 5.06 & 3.73 & 298.10 & 39.13 & 75 \\
\hline 6 & Torbat-Heidarieh & Control & 0.64 & 11.08 & 28.24 & 5.57 & 3.21 & 314.89 & 41.20 & 70 \\
\hline 6 & Gonabad & $\mathrm{Fe}$ & 0.43 & 8.17 & 26.22 & 5.03 & 3.69 & 311.41 & 40.62 & 74 \\
\hline 6 & Gonabad & $\mathrm{P}$ & 0.41 & 7.99 & 26.27 & 5.12 & 3.63 & 296.94 & 37.23 & 81 \\
\hline 6 & Gonabad & $\mathrm{K}$ & 0.37 & 8.40 & 25.04 & 4.76 & 3.73 & 297.00 & 41.75 & 80 \\
\hline 6 & Gonabad & Control & 0.28 & 7.77 & 23.72 & 4.64 & 3.06 & 275.39 & 37.60 & 93 \\
\hline 8 & Birjand & $\mathrm{Fe}$ & 1.11 & 21.43 & 26.62 & 5.17 & 3.28 & 335.60 & 43.83 & 57 \\
\hline 8 & Birjand & $\mathrm{P}$ & 1.00 & 20.13 & 26.97 & 5.00 & 3.52 & 326.39 & 40.74 & 69 \\
\hline 8 & Birjand & $\mathrm{K}$ & 0.90 & 19.73 & 26.43 & 4.67 & 3.40 & 325.50 & 42.15 & 71 \\
\hline 8 & Birjand & Control & 0.84 & 19.61 & 24.87 & 4.52 & 2.72 & 327.07 & 41.89 & 76 \\
\hline 8 & Torbat-Jam & $\mathrm{Fe}$ & 1.17 & 20.70 & 30.59 & 5.48 & 3.47 & 341.00 & 43.83 & 40 \\
\hline 8 & Torbat-Jam & $\mathrm{P}$ & 1.19 & 20.38 & 27.58 & 5.41 & 3.54 & 323.83 & 40.74 & 59 \\
\hline 8 & Torbat-Jam & $\mathrm{K}$ & 1.02 & 19.04 & 28.33 & 5.21 & 3.54 & 334.83 & 42.15 & 53 \\
\hline 8 & Torbat-Jam & Control & 0.97 & 19.04 & 29.39 & 5.39 & 2.90 & 321.29 & 41.89 & 63 \\
\hline 8 & Ghaen & $\mathrm{Fe}$ & 0.96 & 18.64 & 26.81 & 5.17 & 3.13 & 335.60 & 44.03 & 62 \\
\hline 8 & Ghaen & $\mathrm{P}$ & 0.93 & 18.79 & 26.64 & 5.00 & 3.64 & 326.39 & 41.73 & 66 \\
\hline 8 & Ghaen & $\mathrm{K}$ & 0.89 & 18.59 & 24.77 & 4.67 & 3.30 & 325.50 & 40.37 & 79 \\
\hline 8 & Ghaen & Control & 0.69 & 16.53 & 25.55 & 4.52 & 2.94 & 327.07 & 38.75 & 85 \\
\hline 8 & Mashhad & $\mathrm{Fe}$ & 1.34 & 21.08 & 31.09 & 6.14 & 3.59 & 355.42 & 44.03 & 30 \\
\hline 8 & Mashhad & $\mathrm{P}$ & 1.20 & 22.86 & 27.72 & 5.12 & 3.18 & 339.18 & 41.73 & 60 \\
\hline 8 & Mashhad & $\mathrm{K}$ & 1.07 & 20.72 & 25.11 & 4.94 & 3.12 & 338.82 & 40.37 & 72 \\
\hline 8 & Mashhad & Control & 1.17 & 20.17 & 26.88 & 5.73 & 3.05 & 339.00 & 38.75 & 64 \\
\hline 8 & Torbat-Heidarieh & $\mathrm{Fe}$ & 1.45 & 21.81 & 30.06 & 6.14 & 3.99 & 355.42 & 43.09 & 26 \\
\hline 8 & Torbat-Heidarieh & $\mathrm{P}$ & 1.31 & 21.01 & 29.69 & 5.70 & 3.45 & 346.29 & 40.81 & 45 \\
\hline 8 & Torbat-Heidarieh & $\mathrm{K}$ & 1.11 & 20.52 & 26.41 & 5.33 & 3.54 & 331.39 & 41.85 & 58 \\
\hline 8 & Torbat-Heidarieh & Control & 1.09 & 19.41 & 29.72 & 5.75 & 3.40 & 339.32 & 41.84 & 46 \\
\hline 8 & Gonabad & $\mathrm{Fe}$ & 1.04 & 18.62 & 26.09 & 5.43 & 3.82 & 341.00 & 43.46 & 49 \\
\hline 8 & Gonabad & $\mathrm{P}$ & 0.99 & 18.54 & 26.44 & 5.00 & 3.61 & 327.22 & 41.51 & 68 \\
\hline 8 & Gonabad & $\mathrm{K}$ & 0.77 & 18.27 & 25.82 & 4.31 & 3.84 & 333.36 & 43.10 & 67 \\
\hline 8 & Gonabad & Control & 0.66 & 17.43 & 24.43 & 4.75 & 3.35 & 319.38 & 39.52 & 84 \\
\hline
\end{tabular}


Table 5. Continue

\begin{tabular}{|c|c|c|c|c|c|c|c|c|c|c|}
\hline Weight & Ecotype & Fertilizer & DSY & FN & FSW & DSW & SL & FFW & DFW & Rank \\
\hline 10 & Birjand & $\mathrm{Fe}$ & 1.70 & 29.52 & 30.00 & 5.50 & 4.14 & 366.41 & 44.54 & 14 \\
\hline 10 & Birjand & $\mathrm{P}$ & 1.57 & 27.85 & 29.69 & 5.66 & 4.14 & 354.84 & 42.45 & 28 \\
\hline 10 & Birjand & $\mathrm{K}$ & 1.44 & 28.84 & 26.87 & 5.05 & 3.88 & 352.45 & 44.24 & 38 \\
\hline 10 & Birjand & Control & 1.14 & 26.20 & 27.84 & 4.62 & 3.19 & 362.84 & 42.77 & 50 \\
\hline 10 & Torbat-Jam & $\mathrm{Fe}$ & 1.58 & 28.84 & 29.61 & 5.40 & 4.14 & 366.41 & 46.74 & 13 \\
\hline 10 & Torbat-Jam & $\mathrm{P}$ & 1.66 & 29.94 & 26.99 & 5.24 & 4.14 & 354.84 & 45.72 & 29 \\
\hline 10 & Torbat-Jam & K & 1.25 & 26.91 & 28.98 & 4.90 & 3.88 & 356.33 & 44.93 & 36 \\
\hline 10 & Torbat-Jam & Control & 1.24 & 26.74 & 28.83 & 4.86 & 3.19 & 358.97 & 43.35 & 48 \\
\hline 10 & Ghaen & $\mathrm{Fe}$ & 1.53 & 27.26 & 26.98 & 5.40 & 3.89 & 369.52 & 46.24 & 27 \\
\hline 10 & Ghaen & $\mathrm{P}$ & 1.54 & 28.40 & 27.06 & 5.24 & 3.65 & 356.70 & 43.85 & 37 \\
\hline 10 & Ghaen & $\mathrm{K}$ & 1.29 & 25.36 & 26.19 & 4.90 & 3.45 & 350.36 & 42.37 & 61 \\
\hline 10 & Ghaen & Control & 1.19 & 23.47 & 26.92 & 4.86 & 3.54 & 359.62 & 40.75 & 56 \\
\hline 10 & Mashhad & $\mathrm{Fe}$ & 1.89 & 28.93 & 32.24 & 6.24 & 3.89 & 372.15 & 46.24 & 9 \\
\hline 10 & Mashhad & $\mathrm{P}$ & 1.86 & 31.64 & 28.99 & 5.58 & 3.65 & 351.73 & 43.85 & 31 \\
\hline 10 & Mashhad & $\mathrm{K}$ & 1.57 & 28.18 & 27.35 & 5.20 & 3.45 & 358.56 & 42.37 & 42 \\
\hline 10 & Mashhad & Control & 1.44 & 26.61 & 30.10 & 5.62 & 3.54 & 351.76 & 40.75 & 39 \\
\hline 10 & Torbat-Heidarieh & $\mathrm{Fe}$ & 2.28 & 33.22 & 31.34 & 6.43 & 4.41 & 369.52 & 46.74 & 5 \\
\hline 10 & Torbat-Heidarieh & $\mathrm{P}$ & 1.90 & 29.43 & 30.32 & 6.24 & 4.17 & 356.70 & 45.22 & 11 \\
\hline 10 & Torbat-Heidarieh & $\mathrm{K}$ & 1.69 & 28.99 & 27.61 & 5.62 & 4.01 & 350.99 & 42.09 & 35 \\
\hline 10 & Torbat-Heidarieh & Control & 1.52 & 26.47 & 29.41 & 5.78 & 3.48 & 358.98 & 46.69 & 25 \\
\hline 10 & Gonabad & $\mathrm{Fe}$ & 1.53 & 26.98 & 26.98 & 5.50 & 4.41 & 372.15 & 44.54 & 20 \\
\hline 10 & Gonabad & $\mathrm{P}$ & 1.54 & 26.87 & 27.06 & 5.66 & 4.17 & 354.60 & 42.45 & 33 \\
\hline 10 & Gonabad & $\mathrm{K}$ & 1.29 & 25.40 & 26.19 & 5.05 & 3.74 & 360.24 & 44.24 & 41 \\
\hline 10 & Gonabad & Control & 1.01 & 25.80 & 26.92 & 4.62 & 3.75 & 347.21 & 42.77 & 51 \\
\hline 12 & Birjand & $\mathrm{Fe}$ & 2.79 & 48.55 & 31.80 & 5.49 & 3.74 & 362.15 & 46.10 & 10 \\
\hline 12 & Birjand & $\mathrm{P}$ & 2.28 & 44.13 & 30.22 & 4.95 & 4.01 & 354.81 & 44.87 & 18 \\
\hline 12 & Birjand & $\mathrm{K}$ & 2.25 & 40.46 & 28.96 & 5.49 & 3.36 & 352.51 & 44.30 & 32 \\
\hline 12 & Birjand & Control & 1.72 & 37.23 & 26.90 & 4.47 & 3.21 & 354.96 & 43.70 & 47 \\
\hline 12 & Torbat-Jam & $\mathrm{Fe}$ & 2.89 & 47.06 & 32.16 & 5.88 & 4.26 & 373.18 & 46.10 & 3 \\
\hline 12 & Torbat-Jam & $\mathrm{P}$ & 3.11 & 45.88 & 29.58 & 5.98 & 4.16 & 360.13 & 44.40 & 7 \\
\hline 12 & Torbat-Jam & $\mathrm{K}$ & 2.25 & 39.70 & 30.46 & 5.46 & 3.94 & 358.65 & 43.66 & 17 \\
\hline 12 & Torbat-Jam & Control & 2.32 & 38.94 & 32.91 & 5.81 & 3.78 & 373.18 & 44.81 & 8 \\
\hline 12 & Ghaen & $\mathrm{Fe}$ & 1.97 & 38.85 & 28.56 & 5.07 & 3.74 & 359.68 & 46.38 & 23 \\
\hline 12 & Ghaen & $\mathrm{P}$ & 2.25 & 42.01 & 29.11 & 5.26 & 4.01 & 354.30 & 44.38 & 19 \\
\hline 12 & Ghaen & $\mathrm{K}$ & 2.23 & 41.00 & 26.93 & 5.17 & 3.36 & 352.30 & 42.66 & 43 \\
\hline 12 & Ghaen & Control & 1.55 & 34.99 & 27.64 & 4.49 & 3.21 & 354.81 & 41.32 & 54 \\
\hline 12 & Mashhad & $\mathrm{Fe}$ & 2.95 & 46.14 & 31.80 & 6.19 & 4.18 & 385.48 & 46.38 & 1 \\
\hline 12 & Mashhad & $\mathrm{P}$ & 2.48 & 45.04 & 29.25 & 5.56 & 3.69 & 366.35 & 44.38 & 12 \\
\hline 12 & Mashhad & $\mathrm{K}$ & 2.79 & 44.08 & 27.85 & 5.81 & 3.41 & 372.98 & 42.66 & 21 \\
\hline 12 & Mashhad & Control & 2.27 & 41.06 & 28.99 & 5.87 & 3.55 & 369.63 & 41.32 & 24 \\
\hline 12 & Torbat-Heidarieh & $\mathrm{Fe}$ & 3.12 & 49.29 & 32.16 & 5.95 & 4.26 & 373.18 & 45.43 & 2 \\
\hline 12 & Torbat-Heidarieh & $\mathrm{P}$ & 3.12 & 44.78 & 31.22 & 6.43 & 4.16 & 372.01 & 44.45 & 4 \\
\hline 12 & Torbat-Heidarieh & $\mathrm{K}$ & 2.67 & 45.58 & 29.41 & 5.84 & 3.94 & 354.13 & 43.36 & 15 \\
\hline 12 & Torbat-Heidarieh & Control & 2.82 & 41.53 & 32.31 & 6.78 & 3.78 & 365.81 & 45.37 & 6 \\
\hline 12 & Gonabad & $\mathrm{Fe}$ & 2.16 & 40.63 & 28.56 & 5.19 & 4.18 & 360.80 & 46.02 & 16 \\
\hline 12 & Gonabad & $\mathrm{P}$ & 2.62 & 42.73 & 29.11 & 5.72 & 3.69 & 339.48 & 44.28 & 22 \\
\hline 12 & Gonabad & $\mathrm{K}$ & 2.11 & 43.28 & 26.93 & 4.92 & 3.41 & 360.01 & 46.41 & 34 \\
\hline 12 & Gonabad & Control & 1.67 & 35.21 & 27.64 & 5.20 & 3.55 & 332.46 & 41.90 & 44 \\
\hline \multicolumn{2}{|c|}{ HSD (5\%) } & & 2.37 & 38.57 & 6.66 & 1.60 & 1.32 & 31.30 & 7.23 & --- \\
\hline
\end{tabular}


Table 6. Correlation coefficients between flowering characteristics in saffron.

\begin{tabular}{llllllll}
\hline & DSY & & & & & \\
FN & 0.98 & FN & & & & \\
FSW & 0.61 & 0.55 & FSW & & & \\
DS & 0.63 & 0.52 & 0.77 & DSW & & \\
SL & 0.51 & 0.47 & 0.57 & 0.55 & SL & \\
FFW & 0.61 & 0.60 & 0.66 & 0.56 & 0.53 & FFW \\
DF & 0.48 & 0.47 & 0.57 & 0.53 & 0.50 & 0.68 \\
\hline
\end{tabular}

Overall, it was concluded that traits FN, DSW and DFW were the most effective traits on DSY. Therefore, any increasing or improvement in these traits will increase DSY. Previous researches have shown that the correct saffron farm management including proper planting date, optimal use of fertilizer, appropriate planting density, selection of larger corms and timely irrigation saffron farms especially in the final stages of the growing season play the most effective roles in markedly improving yield components and subsequently increasing saffron in the first year and the coming years. Molina, et al., (2005) and Vurdu, et al., (2002) pointed out that mature and bigger corms gave more flowers and daughter corms. Therefore, one of the objectives in production of saffron is to obtain bigger corms (Omidbaigi, 2005).

Table 7. Regression coefficients of saffron yield using stepwise method.

\begin{tabular}{|c|c|c|c|c|c|c|c|}
\hline \multirow[t]{2}{*}{ Year } & \multirow[t]{2}{*}{ Model } & Unstar & Coefficients & \multirow{2}{*}{$\begin{array}{l}\text { Standardized } \\
\text { Coefficients } \\
\text { Beta }\end{array}$} & \multirow[t]{2}{*}{$\mathbf{t}$} & \multirow[t]{2}{*}{$\mathbf{R 2}$} & \multirow{2}{*}{$\begin{array}{l}\text { Durbin } \\
\text { Watson }\end{array}$} \\
\hline & & B & Std.Error & & & & \\
\hline \multirow{7}{*}{2013} & Intercept & -1.512 & 0.242 & --- & $-6.253 * *$ & & \\
\hline & $\mathrm{FN}$ & 0.036 & 0.005 & 0.494 & $6.665 * *$ & & \\
\hline & DSW & 0.207 & 0.029 & 0.424 & $7.149 * *$ & & \\
\hline & SL & 0.117 & 0.026 & 0.179 & $4.582 * *$ & & \\
\hline & FSW & -0.022 & 0.008 & -0.186 & $-2.91 * *$ & & \\
\hline & FFW & 0.003 & 0.001 & 0.215 & $2.813 * *$ & & \\
\hline & & & & & & 0.91 & 1.367 \\
\hline \multirow{6}{*}{2014} & Intercept & -0.732 & 0.295 & --- & $-2.480 *$ & & \\
\hline & FN & 0.058 & 0.001 & 0.934 & $54.293 * *$ & & \\
\hline & DSW & 0.398 & 0.023 & 0.214 & $17.256 * *$ & & \\
\hline & DFW & -0.019 & 0.005 & -0.044 & $-3.416 * *$ & & \\
\hline & FFW & -0.002 & 0.001 & -0.041 & $-2.177 *$ & & \\
\hline & & & & & & 0.99 & 1.718 \\
\hline \multirow{5}{*}{ Total } & Intercept & -0.901 & 0.145 & --- & $-6.218 * *$ & & \\
\hline & FN & 0.056 & 0.001 & 0.911 & $91.323 * *$ & & \\
\hline & DSW & 0.304 & 0.017 & 0.181 & $17.486 * *$ & & \\
\hline & DFW & -0.017 & 0.004 & -0.046 & $-4.556 * *$ & & \\
\hline & & & & & & 0.99 & 1.96 \\
\hline
\end{tabular}

${ }^{\mathrm{a}}$ - Abbreviations are described in materials and methods

\section{CONCLUSIONS}

Results showed significant differences between years, nanofertilizers, maternal corm weights, saffron ecotypes and their interactions in terms of all flowering traits. Furthermore, it was clear that nanofertilizers (especially $\mathrm{Fe}$ ) compared to the control increased the production of all these traits. Meteorological data illustrated that TorbatHeydarieh, Urmia and Mashhad regions have the same climatic. However, it was the ecotypes of TorbatHeydarieh and Mashhad regions that had the highest saffron yield in the Urmia region. On the other hand, it was highlighted that maternal corm weight had more positive effects on flowering traits rather than nanofertilizers and saffron ecotypes. Increasing maternal corm weight from 6 to 12 grams conferred an increase in all traits, especially dry saffron yield, at an increase of 5.17 times and flower number, an increase of 4.4 times. From the results of the stepwise regression and correlation coefficients, it was determined that the following traits: flowers number, dry stigma weight and dry flower weight, were the most effective indicators of dry saffron yield. In general, it can be concluded that the yield and flowering traits of saffron are strongly influenced by environmental conditions and farm management. Therefore, the correct choice of saffron ecotypes, nanofertilizer and maternal corm weight can be considered the most crucial factors in farm management and economic production of saffron.

\section{LITERATURE CITED}

Abdullaev, F.I. 2003. Crocus sativus against cancer. Archives of Medical Research 34(4)354.

Anastasaki, E., C. Kanakis, C. Pappas, L. Maggi, C.P. del Campo, M. Carmona, G.L. Alonso and M.G. Polissiou. 2010. Differentiation of saffron from four countries by midinfrared spectroscopy and multivariate analysis. Eur. Food. Res. Technol. 230:571-577.

Azarpour, E., J. Asghari, H.R. Bozorgi1 and G. Kamalpour. 2013. Foliar Spraying of Ascophyllum nodosum Extract, Methanol and Iron Fertilizers on Fresh Flower Cover yield of Saffron plant (Crocus sativus L.). International Journal of Agriculture and Crop Sciences. 5 (17): 1854-1862.

Azizbekova, N.S.H. and E.L. Milyaeva. 1999. Saffron in cultivation in Azerbaijan. In: Negbi, M. (Ed.), Saffron: Crocus sativus L. Harwood Academic Publishers, Australia, pp. 63-71. 
Baruah, S. and J. Dutta. 2009. Nanotechnology applications in sensing and pollution degradation in agriculture. Env. Chem. Letters J. 7: 191-204.

Bateman, A.S. and S.D. Kelly. 2007. Fertilizer nitrogen isotope signatures. Isotopes in Environmental and Health Studies. 43(3) 237-247.

Behnia, M.R., A. Estilai and B. Ehdaie. 1999. Application of fertilizers for increased saffron yield. J. Agro. Sci. 182 (1) 915.

Behzad, S., M. Razavi and M. Mahajeri. 1992. The effect of mineral nutrients (N.P.K.) on saffron production. International Symposium on Medicinal and Aromatic Plants, Acta Horti. 306:426-430. P. 75.

Botella, O., J.A. de Juan, M.A.R. Munoz, A. Moya and H. López Córcoles. 2002. Descripción morfológica y ciclo anual del azafrán (Crocus sativus L.). Cuadernos de Fitopatología 71, $18-28$.

Castillo, R., J.A. Fernandez and L. Gomez-Gomez. 2005. Implications of Carotenoid Biosynthetic Genes in Apocarotenoid Formation during the Stigma Development of Crocus sativus and Its Closer Relatives. Plant Physiology. 139:674-689.

De Juan, A., A. Moya, S. López, O. Botella, H. López and R. Mu noz. 2003. Influence of the corm size and the density of plantation in the yield and the quality of the production of corms of Crocus sativus L. ITEA. 99:169-180.

De Mastro, G. and C. Ruta. 1993. Relation between corm size and saffron (Crocus sativus L.) flowering. Acta Hortic. 334:512-517.

Fernandez, J.A. 2004. Recent Res. Dev. Pl. Sci. 2:127-159.

Gómez-Gómez, L., A. Trapero-Mozosa, M. Dolores Gómezc, A. Rubio-Moragaa and O. Ahrazem. 2012. Identification and possible role of a MYB transcription factor from saffron (Crocus sativus). Journal of Plant Physiology. 169:509515.

Gresta, F., G. Avola, G.M. Lombardo, L. Siracusa and G. Ruberto. 2009. Analysis of flowering, stigmas yield and qualitative traits of saffron (Crocus sativus L.) as affected by environmental conditions. Sci. Hortic. 119(3) 320-324.

Jalali-Heravi, M., H. Parastar and H. Ebrahimi-Najafabadi. 2010. Self-modeling curve resolution techniques applied to comparative analysis of volatile components of Iranian saffron from different regions. Analytica Chimica Acta. 662:143-154.

Juana, J.A.D., H.L. Córcolesb, R.M. Munozb and M.R. Picornella. 2009. Yield and yield components of saffron under different cropping systems. Industrial Crops and Products. 30:212-219.

Kafi, M., 2006. Saffron ecophysiology. In: Kafi, M., Koocheki, A., Rashed, M.H., Nassiri, M. (Eds.), Saffron (Crocus sativus) Production and Processing. Science Publishers, Enfield, pp. 39-58.

Kole, C., P. Kole, K.M. Randunu, P. Choudhary, R. Podila, P.C. Ke, A.M. Rao and R.K. Marcus. 2013. Nanobiotechnology can boost crop production and quality: first evidence from increased plant biomass, fruit yield and phytomedicine content in bitter melon (Momordica charantia). BMC Biotechnology. 13(37): 1472-6750.

Lage, M. and C.L. Cantrell. 2009. Quantification of saffron (Crocus sativus L.) metabolites crocins, picrocrocin and safranal for quality determination of the spice grown under different environmental Moroccan conditions. Scientia Horticulturae. 121 (3) 366-373.

Liu, X.M., F.D. Zhang, S.Q. Zhang, X.S. He, R. Fang, Z. Feng and Y. Wang. 2010. Effects of nano-ferric oxide on the growth and nutrients absorption of peanut. Plant Nutr Fert Sci. 11:14-18.
Ma, X.Q., D.Y. Zhu, C.S.P. Li, T.T.K. Dong, K.W.K. Tsim. 2001. Authentic identification of stigma croci (stigmas of Crocus sativus) from its adulterants by molecular genetics analysis. Planta Med. 67:183-186.

Maggi, L., M. Carmona, S.D. Kelly, N. Marigheto and G.L. Alonso. 2011. Geographical origin differentiation of saffron spice (Crocus sativus L. stigmas) Preliminary investigation using chemical and multi-element $(\mathrm{H}, \mathrm{C}, \mathrm{N})$ stable isotope analysis. Food Chemistry. 128:543-548.

McGimpsey, J., M. Douslas and A. Wallace. 1997. Evaluation of saffron (Crocus sativus L.) production in New Zealand. N. Z. J. Crop Hortic. Sci. 25:159-168.

Molina, R.V., M. Valero, Y. Navarro, A. Garc'ia-Luis and J.L. Guardiola. 2004. The effect of time of corm lifting and duration of incubation at inductive temperature on flowering in the saffron plant (Crocus sativus L.). Scientia Horticulturae. 103:79-91.

Molina, R.V., M. Valero, Y. Navarro, A. Garci'a-Luis, J.L. Guardiola. 2005. Low temperature storage of corms extends the flowering season of saffron (Crocus sativus L.). J. Hort. Sci. Biotechnol. 80:319-326.

Mollafilabi, A., 2004. Experimental findings of production and echophysiological aspects of saffron (Crocus sativus L.). In: Fernández, J., Abdullaev, F. (Eds.), Proceeding of the 1st on Saffron, Albacete, Spain. Acta Hortic. 650:195-200.

Naderi, M.R. and A. Danesh-Shahraki. 2013. Nanofertilizers and their roles in sustainable agriculture. International Journal of Agriculture and Crop Sciences. 5(19): 2229-2232.

Negbi, M., 1999. Saffron cultivation: past, present and future prospect. In: Negbi, M. (Ed.), Saffron: Crocus sativus L. Harwood Academic Publishers, Australia, pp. 1-18.

Omidbaigi, R., 2005. Effects of corm weight on quality of Saffron (Crocus sativus Linn.), Nat. Prod. Radinace, 4:193194.

Ordoudi E, Tsimidou M. 2004. Saffron quality: Effect of agricultural practices, processing and storage. In Production Practices and Quality Assessment of Food Crops Edited by: Dris R, Jain SM. Dordrecht The Netherlands Kluwer Academic Publishers. 209-260.

Rees, A.R., 1992. Ornamental Bulbs, Corms and Tubers. C.A.B. International, Wallingford, UK.

Renau-Morata, B., S.G. Nebauer, M. Sánchez and R.V. Molina. 2012. Effect of corm size, water stress and cultivation conditions on photosynthesis and biomass partitioning during the vegetative growth of saffron (Crocus sativus L.). Industrial Crops and Products. 39:40-46.

Rico, C.M., S. Majumdar, M. Duarte-Gardea, J.R. Peralta-Videa and J.L. Gardea-Torresdey. 2011. Interaction of nanoparticles with edible plants and their possible implications in the food chain. J Agric Food Chem. 59:3485-3498.

Rubio-Moraga, A., R. Castillo-López, L. Gómez-Gómez and O. Ahrazem. 2009. Saffron is a monomorphic species as revealed by RAPD, ISSR and microsatellite analyses. BMC Research Notes. 2:1-5.

Salinger, J.P., 1991. Producción comercial de flores. Butterworths of New Zealand, Wellington, NZ.

Sampathu, S.R., Shivashankar, S., Lewis, Y.S., 1984. Saffron (Crocus sativus L.): cultivation, processing, chemistry and standardization. Critical Reviews in Food Science and Nutrition. 20:123-157.

Schmidt, M., G. Betti and A. Hensel. 2007. Saffron in phytotherapy: Pharmacology and clinical uses. Wiener medizinische Wochenschrift. 157:315-319.

Siracusa, L., F. Gresta, G. Avola, G.M. Lombardo and G. Ruberto. 2010. Influence of corm provenance and environmental condition on yield and apocarotenoid profiles 
in saffron (Crocus sativus L.). Journal of Food Composition and Analysis. 23: 394-400.

Turhan, H., F. Kahriman, C.O. Egesel and M.K. Gul. 2007. The effects of different growing media on flowering and corm formation of saffron (Crocus sativus L.). African Journal of Biotechnology. 6(20): 2328-2332.

Unal, M. and A. Cavusoglu. 2005. The effect of various nitrogen fertilizers on saffron (Crocus sativus L.) yield. Akdeniz
University Journal of Agriculture Faculty (in Turkish). 18(2) 257-260.

Vurdu, H., Z. Laltu and S. Ayan. 2002. Crocus sativus L. culture technique. Gazi Uni. Journal of Forest Faculty (in Turkish). 2:175-187.

Zdemür, C., P. Baran and Y. Akyol. 2006. The Morphology and Anatomy of Crocus flavus Weston subsp. flavus (Iridaceae). Turk J Bot. 30:175-180. 